\title{
Analisis SWOT Terhadap Layanan Kardiovaskular Eka Hospial Pekanbaru
}

\author{
Deny , Machasin ,Jahrizal
}

Magister Manajemen Universitas Riau, Pekanbaru, Riau, Indonesia

\begin{abstract}
This study aimed to determine strategy for business unit based on quantitative SWOT analysis. This study was conducted in Eka Hospital Pekanbaru with the subject of research was Cardiovascular Services of Eka Hospital Pekanbaru. This study uses a qualitative analysis with internal data (primary data) and external data (secondary data). Sample of this study are individuals in hospital management. Determination of strategic factors in internal and external factors, ranking and weighting of each factor in the IFAS table and in the EFAS table was done through a Group Group Discussion (FGD). X value is obtained from the difference of total multiplication rating and weight of all factors in strength factors minus total multiplication rating and weight of all factors in the weakness factors. $X$ value is 0.69 (possitive). $Y$ value is obtained from the difference of total multiplication rating and weight of all factors in the ofactors minus total multiplication rating and weight of all factors in the weakness factors. $Y$ value is 0.30 , also possitive. Projection of $X$ and $Y$ in the SWOT quadrant are in the first quadrant. It means that progressive strategy (growth oriented strategy) is the recommended strategy because Eka Hospital Pekanbaru has strengths and good opportunities. Functional strategies are formulated based on progressive strategy as the recommendations strategy for business unit.
\end{abstract}

Keywords: IFAS, EFAS, FGD, Progressive Strategy

Email Address : deny1@gmail.com

\section{Pendahuluan}

Industri rumah sakit di Indonesia menunjukkan pertumbuhan termasuk di Propinsi Riau. Hal ini ditandai dengan peningkatan jumlah rumah sakit di Indonesia maupun di Riau. Berdasarkan data Kementerian Kesehatan Republik Indonesia, jumlah rumah sakit di Indonesia mencapai 2.813 di akhir tahun 2018 dengan 2.269 atau $80.66 \%$ adalah rumah sakit umum dan 544 rumah sakit merupakan rumah sakit khusus. Sekitar 1.787 atau $63.53 \%$ merupakan rumah sakit swasta.

Grafik 1.1. Distribusi Rumah Sakit Tahun 2018 Berdasarkan Kepemilikan

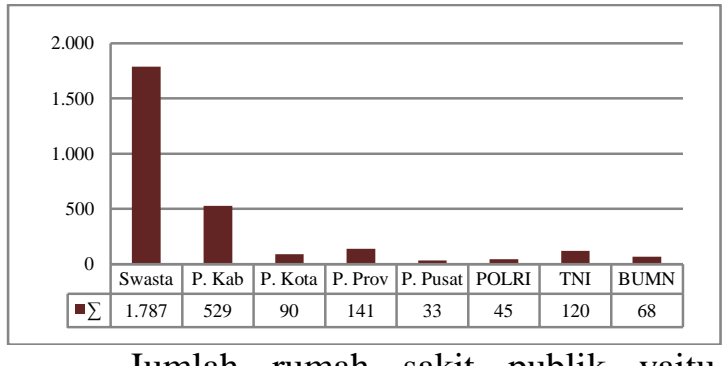

Jumlah rumah sakit publik yaitu rumah sakit yang dikelola pemerintah pusat, propinsi, kabupaten / kota, POLRI, TNI dan BUMN hanya meningkat $2.08 \%$ di tahun 2018 dibandingkan tahun 2012 dengan ratarata peningkatan pertahun $0.39 \%$. Hal ini berbeda bermakna dengan peningkatan jumlah rumah sakit privat yaitu rumah sakit yang dikelola swasta, yayasan atau lembaga sosial non profit yang meningkat $129.83 \%$ di tahun 2018 dibandingkan tahun 2012 dengan 
rata-rata pertumbuhan pertahun mencapai $15.27 \%$.

Grafik 1.2. Pertumbuhan Rumah Sakit Publik dan Privat 2012 - April 2018

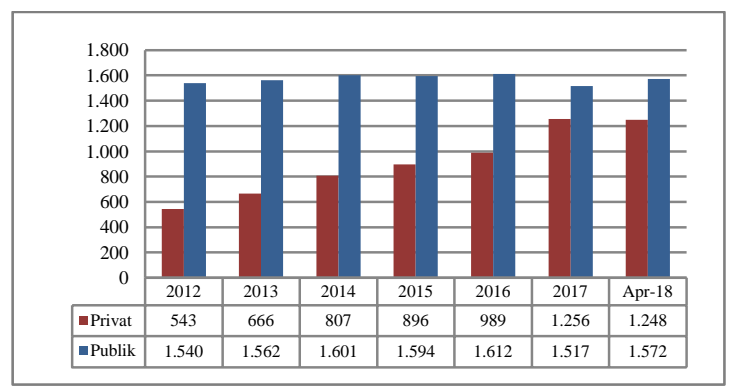

Berdasarkan data Perhimpunan Rumah Sakit Seluruh Indonesia (PERSI) Propinsi Riau dan Badan Pusat Statistik (BPS) Propinsi Riau tahun 2018, jumlah rumah sakit di Riau adalah 73 dan tersebar di kabupaten/kota dengan $44 \%$ berada di Kota Pekanbaru.

Tabel 1.1. Jumlah Rumah Sakit di Riau Berdasarkan Klasifikasi

\begin{tabular}{|l|c|}
\hline \multicolumn{1}{|c|}{ Klasifikasi Rumah Sakit } & Jumlah \\
\hline Rumah Sakit tipe A & 1 \\
\hline Rumah Sakit tipe B & 7 \\
\hline Rumah Sakit tipe C & 40 \\
\hline Rumah Sakit tipe D & 24 \\
\hline Rumah Sakit non kelas & 1 \\
\hline Jumlah & 73 \\
\hline
\end{tabular}

Jumlah rumah sakit di Riau mengalami peningkatan $38.46 \%$ di tahun 2018 dibandingkan tahun 2012 dan didominasi pertumbuhan rumah sakit privat yang dikelola swasta. Tingkat pertumbuhan yang relatif tinggi dalam lima tahun terakhir tersebut menunjukkan bahwa bisnis rumah sakit memiliki daya tarik yang kuat. Potensi profit yang besar menjadi daya tarik utama pertumbuhan industri rumah sakit. Pertumbuhan rumah sakit privat swasta akan meningkatkan kompetisi di antara rumah sakit terutama antar rumah sakit privat swasta termasuk dalam bidang layanan kardiovaskular.

Layanan kardiovaskular adalah layanan yang berkaitan dengan penyakit kardiovaskular yaitu penyakit jantung dan pembuluh darah. Penyakit kardiovaskular merupakan penyebab utama kematian di dunia. Berdasarkan data WHO, sekitar 17.7 juta jiwa meninggal dunia di tahun 2015 karena penyakit kardiovaskular dan merupakan $31 \%$ dari seluruh kematian di dunia di tahun yang sama. Sekitar 7.4 juta dari 17.7 juta kematian tersebut disebabkan oleh penyakit jantung koroner. Jumlah ini meningkat dibandingkan data WHO di tahun 2013 dengan 17.3 juta kematian akibat penyakit kardiovaskular atau $30 \%$ dari seluruh kematian di dunia di tahun yang sama dan dengan 7.3 juta kematian di antaranya disebabkan penyakit jantung koroner. WHO memperkirakan angka kematian yang disebabkan penyakit kardiovaskular akan mencapai 23.600.000 jiwa di tahun 2030 .

Sekitar $80 \%$ dari kematian karena penyakit kardiovaskular terjadi di negara- negara berpenghasilan rendah dan sedang (low middle income) termasuk Indonesia.

Berdasarkan data Riset Kesehatan Dasar (RISKESDAS) tahun 2013, penyakit jantung dan pembuluh darah merupakan penyebab utama kematian di Indonesia dengan $17.05 \%$ dari jumlah seluruh penyebab kematian di Indonesia. RISKESDAS 2018 mencatat prevalensi penyakit jantung koroner di Indonesia mencapai $1.5 \%$ dari populasi penduduk. Data prevalensi di Riau sebagai berikut:

- Prevalensi penyakit jantung koroner di Riau $1.1 \%$ dari populasi penduduk.

- Prevalensi hipertensi pada kelompok usia $\geq 18$ tahun di Riau mencapai $8.44 \%$ populasi berdasarkan diagnosis dokter atau riwayat menggunakan obat anti hipertensi.

- Prevalensi hipertensi pada kelompok usia $\geq 18$ tahun di Riau mencapai 29.14\% populasi berdasarkan data pengukuran tekanan darah.

- Prevalensi penyakit diabetes melitus di Riau mencapai $1.3 \%$ dari populasi dan $1.9 \%$ dari populasi kelompok usia $\geq 15$ tahun.

Penyakit hipertensi dan diabetes mellitus merupakan bagian dari faktor risiko utama penyakit jantung koroner. Prevalensi penyakit jantung bawaan atau kongenital mencapai sekitar 48.800 jiwa dari 6.600 .000 jiwa kelahiran hidup pertahun. 
Prevalensi di atas menunjukkan potensi pasar yang besar di Propinsi Riau. Potensi pasar yang besar ini merupakan potensi revenue yang besar untuk industri rumah sakit terutama kelompok rumah sakit yang memiliki layanan di bidang kardiovaskular dan menjadi daya tarik untuk dipenetrasi oleh rumah sakit yang belum memiliki layanan di bidang kardiovaskular.

Biaya langsung dan biaya tidak langsung akibat penyakit jantung dan pembuluh darah mencapai lebih dari $\$ 316$ miliar setiap tahun di Amerika Serikat. Biaya ini mencakup biaya pemeriksaan, biaya obat, biaya perawatan dan biaya akibat kehilangan produktivitas. Salah satu beban pembiayaan yang besar dari pengelolaan BPJS berkaitan dengan pembiayaan untuk penyakit jantung. Risiko biaya yang besar yang timbul dalam pengobatan dan perawatan pasien penyakit jantung dan pembuluh darah disertai prevalensi penyakit yang tinggi merupakan potensi revenue yang besar untuk industri rumah sakit dan menjadi daya tarik dalam lingkungan industri rumah sakit.

Permenkes Nomor 56 tahun 2014 tentang klasifikasi dan perizinan rumah sakit menetapkan rumah sakit yang wajib memiliki layanan spesialis jantung dan pembuluh darah adalah rumah sakit tipe A dan B. Dalam lingkungan industri rumah sakit di Riau, layanan spesialis jantung dan pembuluh darah dapat pula ditemukan di rumah sakit tipe $\mathrm{C}$ di Pekanbaru. Fakta ini menunjukkan layanan kardiovaskular memiliki daya tarik untuk dikembangkan oleh banyak rumah sakit karena potensi revenue yang besar seperti yang disebutkan di atas. Hal ini menyebabkan kompetisi antar rumah sakit semakin kompetitif dalam bidang layanan kardiovaskular.

Eka Hospital telah menetapkan layanan kardiovaskular sebagai salah satu layanan unggulan dan menjadi salah satu fokus dalam pengembangan layanan. Hal ini diwujudkan dengan menjadikan layanan kardiovaskular sebagai prioritas dalam investasi infrastruktur penunjang layanan, pengembangan sumber daya manusia,

kegiatan pemasaran, pemantauan mutu dan kegiatan lain. Langkah-langkah tersebut identik dengan strategi agresif (growth oriented strategy).

Layanan rawat jalan spesialis jantung dan pembuluh darah Eka Hospital Pekanbaru mengalami pertumbuhan setiap tahun sejak tahun 2011 sampai tahun 2018 dengan ratarata peningkatan pertahun mencapai $29.98 \%$. Peningkatan tertinggi terjadi di tahun 2012, mencapai $111.6 \%$ dibandingkan di tahun 2011. Walaupun mengalami pertumbuhan setiap tahun namun tingkat pertumbuhan mengalami penurunan dalam tiga tahun terakhir yaitu $12.92 \%$ di tahun $2016,9.87 \%$ di tahun 2017 dan $9.65 \%$ di tahun 2018.

Grafik 1.3. Pertumbuhan Kunjungan Rawat Jalan ke Klinik Spesialis Jantung Tahun 2011 - 2018

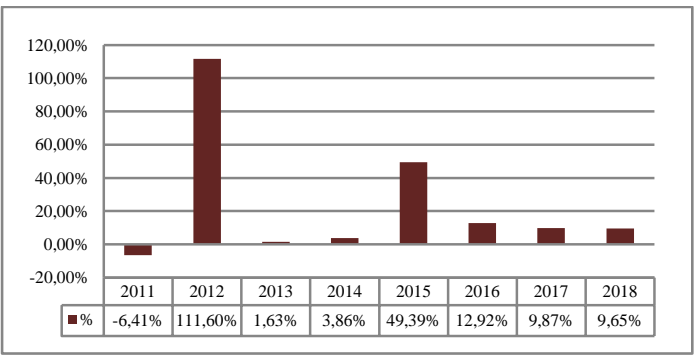

Layanan bedah jantung dimulai di November 2014 untuk melengkapi layanan kardiovaskular Eka Hospital. Jumlah pasien bedah jantung mengalami penurunan $4.76 \%$ di tahun 2016 dan penurunan yang relatif besar di tahun 2017 mencapai 45\%. Di tahun 2018, jumlah pasien bedah jantung mengalami peningkatan $48 \%$ dibanding di tahun 2017 namun jumlah pasien bedah jantung di tahun tersebut tersebut masih lebih rendah dibandingkan di tahun 2015.

Jumlah prosedur
pembuluh darah jantung meterisasi
penurunan $11.86 \%$ di tahun 2016 dibanding di
tahun 2015 dan penurunan $16.36 \%$ di tahun
2017 dibandingkan di tahun 2016. Di tahun
2018 mengalami peningkatan kembali
$42.27 \%$ dibanding di tahun 2017.


Grafik 1.4. Pertumbuhan Jumlah Prosedur Kateterisasi Jantung 2010 - 2018

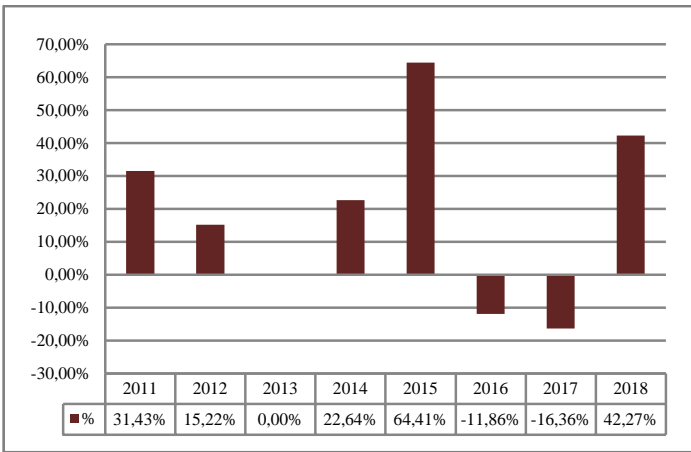

Tingkat pertumbuhan yang tidak konsisten memerlukan evaluasi oleh manajemen rumah sakit. Penurunan akan memberikan dampak pada penurunan revenue dari layanan kardiovaskular. Dalam upaya mencapai pertumbuhan yang konsisten, Eka Hospital perlu memilih strategi yang sesuai untuk layanan kardiovaskular dan merumuskan strategi - strategi di tingkat fungsional yang tepat. Eka Hospital juga perlu mengevaluasi strategi yang telah diterapkan sebelumya dan kesesuaian strategi tersebut dengan perubahan dan perkembangan industri rumah sakit terutama di Riau.

Untuk memilih strategi yang sesuai, diperlukan penilaian posisi layanan kardiovaskular yang dimiliki terhadap layanan kardiovaskular yang dimiliki rumah sakit lain di Riau. Penilaian ini membutuhkan analisis terhadap kekuatan, kelemahan, peluang dan ancaman layanan kardiovaskular yang dimiliki. Analisis harus mencakup pula analisis pasar, kompetitor, regulasi, perkembangan ilmu pengetahuan dan teknologi di bidang kardiovaskular dan faktor faktor lain.

Analisis SWOT merupakan salah satu metode yang dapat digunakan untuk analisa kekuatan, kelemahan, peluang dan ancaman untuk menentukan rekomendasi strategi yang sesuai berdasarkan posisi di dalam kuadran SWOT. Data yang lengkap dan akurat serta kedalaman analisis akan menentukan akurasi hasil analisis. Analisis SWOT sering digunakan bersama metode lain di dalam perencanaan strategis. Analisis SWOT merupakan prekursor perencanaan strategis dengan melibatkan sejumlah individu yang memiliki kompetensi menilai organisasi dari perspektif kritis dan memiliki kewenangan dalam pengambilan keputusan dalam organisasi. Berdasarkan posisi di dalam kuadran SWOT akan didapatkan rekomendasi strategi. Rekomendasi strategi tersebut akan menjadi dasar dalam perumusan strategi tingkat fungsional.

\section{Rumusan Masalah dan Tujuan}

Penelitian ini ingin menilai dan merumuskan:

- Faktor faktor internal yang menjadi kekuatan dan kelemahan dari layanan kardiovaskular

- Faktor faktor eksternal yang menjadi peluang dan ancaman layanan kardiovaskular

- Posisi dari layanan kardiovaskular yang dimiliki dalam lingkungan industri rumah sakit sejenis di Riau.

- Rekomendasi strategi pengembangan layanan kardiovaskular berdasarkan posisi di dalam kuadran SWOT

- Strategi fungsional yang perlu dilakukan berdasarkan rekomendasi itu.

\section{Kerangka Teori}

\section{Strategi}

Strategi merupakan alat yang digunakan untuk mencapai tujuan. Konsep tentang strategi mengalami perkembangan dari waktu ke waktu. Berbagai konsep mengenai strategi yang dikenal berkaitan dengan dua hal utama yaitu:

1. Disctinctive Competencies

Upaya spesifik yang dilakukan perusahaan untuk dapat melakukan lebih baik dibandingkan kompetitor dan tidak mudah ditiru, meliputi efisiensi, mutu, inovasi dan respon terhadap pelanggan.

2. Competitive Advantage

Kegiatan spesifik yang dikembangkan perusahaan untuk menjadi lebih unggul dibandingkan kompetitor, misal melalui strategi diferensiasi, strategi kepemimpinan harga dan strategi fokus. 


$$
\text { menjadi: }
$$

Strategi dapat pula dikelompokan

1. Strategi Manajemen

Strategi dengan orientasi untuk pengembangan secara makro, antara lain strategi pengembangan produk, strategi pengembangan pasar, strategi penetapan harga, strategi akuisisi, strategi keuangan.

\section{Strategi Investasi}

Strategi dengan orientasi untuk investasi antara lain strategi yang berkaitan dengan penetrasi pasar baru, strategi divestasi dan strategi pembentukan divisi baru.

\section{Strategi Bisnis}

Strategi dengan orientasi pada fungsi fungsi manajemen, antara lain strategi pemasaran, strategi produksi atau operasional, strategi distribusi, strategi yang berhubungan dengan keuangan. Strategi bisnis disebut pula sebagai strategi fungsional.

Strategi berdasarkan tingkatan dapat dibedakan menjadi sebagai:

1. Strategi Tingkat Korporat

Strategi yang berkaitan dengan penentuan jenis bisnis yang akan dikembangkan, dipertahankan atau yang akan dilepas. Strategi ini juga berkaitan dengan keputusan untuk memasuki pasar baru dengan produk baru atau diversifikasi, cara masuk ke bisnis (acqusition, joint venture, internal development) dan cara keluar dari bisnis (liquidatoni, spin off, sell off). Strategi tingkat korporat menjadi panduan untuk penyusunan strategi tingkat unit bisnis dan strategi tingkat fungsional. Strategi yang disusun di setiap tingkatan merupakan kesatuan yang saling terkait untuk menciptakan sinergi untuk performa perusahaan.

\section{Strategi Tingkat Unit Bisnis}

Strategi yang memiliki karakteristik antara lain menghasilkan produk atau jasa yang berkaitan dengan misi, menghasilkan produk atau jasa secara spesifik dan bersaing dengan pesaing yang telah diketahui dengan jelas. Strategi di tingkat unit bisnis dapat meliputi satu atau lebih divisi, lini produk atau berupa satu jenis produk atau merk.

3. Strategi di Tingkat Fungsional

Strategi yang dirumuskan lebih spesifik sesuai kegiatan fungsional manajemen. Strategi ini lebih bersifat operasional karena akan langsung diimplementasikan oleh fungsi fungsi manajemen yang dimiliki organisasi, antara lain fungsi manajemen sumber daya manusia, manajemen keuangan, manajamen operasional, manajemen pemasaran.

\section{Perencanaan Strategi}

Perencanaan strategi merupakan proses penyusunan strategi perusahaan dan merupakan hal penting untuk dapat memperoleh keunggulan bersaing dan memiliki produk atau jasa yang sesuai kebutuhan konsumen dengan dukungan yang optimal dari sumber daya yang dimiliki perusahaan.

Perencanaan strategi melalui tahap pengumpulan data, analisis data dan pengambilan keputusan.

\section{Pengumpulan Data}

Pengumpulan data merupakan proses pra-analisis. Data mencakup data internal dan eksternal. Data internal yaitu data organisasi meliputi antara lain data sumber daya manusia, data keuangan, data operasional, data pemasaran dan data internal lain. Data eksternal mencakup antara lain data mengenai pasar, kompetitor, peraturan perundangan yang berlaku dan data lain. Data yang lengkap dan akurat merupakan hal yang paling penting pada tahap ini.

\section{Analisis}

Analisis dilakukan terhadap data internal maupun data eksternal, data primer maupun sekunder. Analisis dapat dilakukan dengan berbagai metode. Salah satu metode yang dapat digunakan 
untuk analisis di tingkat unit bisnis adalah analisis SWOT.

3. Pengambilan Keputusan

Pengambilan keputusan mengenai pilihan strategi dilakukan berdasarkan analisis di atas.

\section{Analisis SWOT}

Analisis SWOT merupakan salah satu alat untuk formulasi strategi. Prinsip analisis ini adalah memaksimalkan faktor kekuatan dan peluang serta meminimalkan faktor kelemahan dan ancaman. Penelitian menunjukkan bahwa kinerja perusahaan dapat ditentukan oleh kombinasi faktor internal (kekuatan, kelemahan) dan faktor eksternal (peluang, ancaman). Identifikasi dan penilaian harus dilakukan oleh sejumlah individu yang memiliki kompetensi dan memahami organisasi atau dengan baik serta memiliki kewenangan dalam perumusan strategi.

Terdapat dua pendekatan dalam analisis SWOT, yaitu:

\section{Pendekatan Kualitatif}

Pendekatan kualitatif dikembangkan oleh Kearns dengan menampilkan 8 kotak, terdiri dari dua kotak faktor eksternal di paling atas dan dua kotak faktor internal di sebelah kiri dan empat kotak lain yang merupakan kotak isu isu strategis yang timbul sebagai hasil titik pertemuan faktor internal dan eksternal.

Tabel 1.2. Tabel Matriks SWOT Kearns

\begin{tabular}{|c|l|l|}
\hline Internal & Peluang & Ancaman \\
\hline Kekuatan & Kuadran I & Kuadran II \\
\hline Kelemahan & $\begin{array}{c}\text { Kuadran } \\
\text { III }\end{array}$ & $\begin{array}{c}\text { Kuadran } \\
\text { IV }\end{array}$ \\
\hline
\end{tabular}

\section{Kuadran I}

Perusahaan di kuadran ini merupakan perusahaan yang kuat dan memiliki peluang yang baik. Rekomendasi strategi yang sesuai adalah strategi progresif (growth oriented strategy) yang mendukung pertumbuhan yang agresif yaitu untuk terus melakukan ekspansi, memperbesar pertumbuhan dan meraih kemajuan secara maksimal.

\section{Kuadran II}

Perusahaan di kuadran ini merupakan organisasi yang kuat namun menghadapi tantangan atau ancaman yang besar. Rekomendasi strategi yang sesuai adalah strategi diversifikasi yaitu organisasi disarankan untuk memperbanyak ragam strategi taktis karena organisasi akan mengalami kesulitan bila hanya bertumpu pada strategi sebelumnya. Diversifikasi dapat meliputi produk atau pasar. Perusahaan juga perlu melakukan upaya mobilisasi sumber daya yang merupakan kekuatan organisasi dengan tujuan untuk memperlunak faktor ancaman bahkan bila dimungkinkan mengubah menjadi faktor peluang.

\section{Kuadran III}

Perusahaan di kuadran ini menghadapi peluang pasar yang besar namun memiliki kelemahan di internal perusahaan. Keadaan ini memberikan pilihan yang tidak jelas, memiliki peluang yang besar namun tidak dapat dimanfaatkan karena kekuatan internal tidak cukup untuk memanfaatkan peluang itu. Rekomendasi strategi yang harus diambil perusahaan adalah mengambil peluang tersebut sebagai langkah investasi dan bersamaan dengan meminimalkan kelemahan internal serta memperbaiki kinerja perusahaan. Pilihan lain adalah melepas peluang yang ada (divestment/ investment).

\section{Kuadran IV}

Perusahaan di kuadran ini menunjukkan organisasi yang lemah dan menghadapi tantangan luar yang besar. Rekomendasi strategi adalah strategi bertahan yaitu mengendalikan kinerja internal agar tidak semakin memburuk dan mengendalikan kerugian yang terjadi (damage control) sehingga akibat yang ditimbulkan tidak lebih buruk dari yang diperkirakan dan secara simultan melakukan upaya untuk terus berupaya membenahi internal organisasi. 
2. Pendekatan Kuantitatif

Data analisis SWOT kualitatif dapat dikembangkan secara kuantitatif melalui perhitungan analisis SWOT yang dikembangkan oleh Pearce dan Robinson sehingga dapat diketahui pasti posisi organisasi di dalam lingkungan industri sejenis. Pemberian nilai rating dan bobot dapat dilakukan berdasarkan Forum Group Discussion (FGD) yang melibatkan sejumlah individu di dalam panel yang memiliki kompetensi dan kewenangan di dalam menilai organisasi atau perusahaan.

\section{Grafik 1.5. Kuadran SWOT}

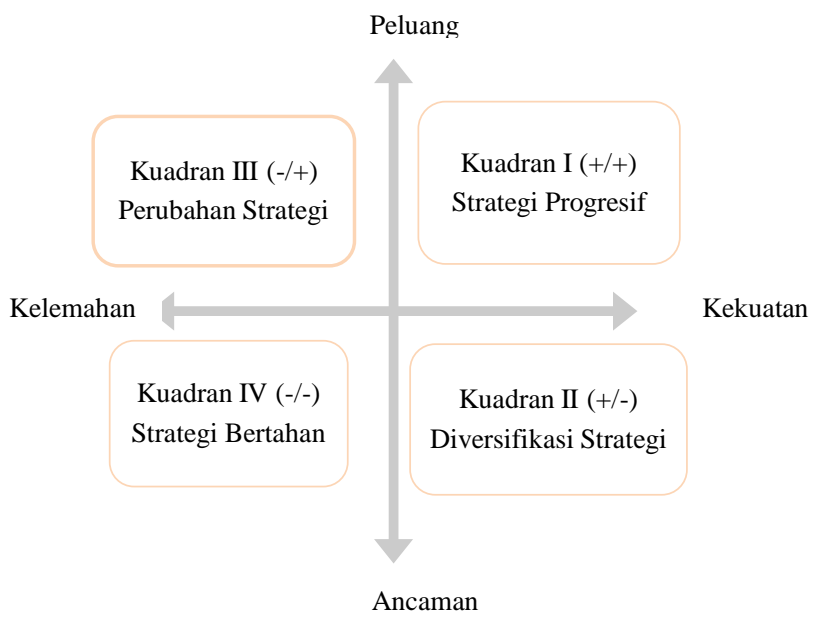

\section{Perumusan Strategi}

Perumusan strategi dimulai dengan strategi di tingkat korporat, dilanjutkan strategi di tingkat unit bisnis dan dirumuskan ke strategi di tingkat fungsional. Analisis SWOT dilakukan untuk merumuskan strategi di tingkat unit bisnis. Strategi di tingkat fungsional merupakan strategi yang dirumuskan secara spesifik pada area area fungsional tertentu untuk mendukung strategi unit bisnis. Strategi tingkat fungsional bertujuan untuk meningkatkan efektifitas dan efisiensi mutu, inovasi dan respon terhadap pelanggan dalam operasional perusahaan.

Area fungsional ini meliputi seluruh divisi di rumah sakit. Kepala divisi memiliki peran untuk mengevaluasi apakah elemen elemen strategis telah dijalankan dengan baik serta memastikan komponen - komponen di dalam strategi fungsional ini mendukung strategi di tingkat unit bisnis maupun strategi di tingkat korporat. Strategi di tingkat fungsional sering berhubungan dengan membangun kekuatan layanan, kekuatan pemasaran, kekuatan keuangan dan kekuatan manajerial.

Strategi tingkat fungsional tersebut terdiri beberapa jenis strategi, antara lain:

1. Strategi bidang sumber daya manusia Strategi ini berkaitan dengan rekrutmen, pemenuhan dan pemanfaatan sumber daya manusia yang kompeten, pembayaran upah dan insentif, pengembangan sumber daya manusia dan hal lain.

2. Strategi bidang pemasaran

Strategi ini berkaitan dengan strategi pemasaran (segmentation, positioning, target), taktik pemasaran (mix of marketing, diferentiation) dan nilai pemasaran (brand, services, process). Beberapa hal yang dapat dilakukan perusahaan antara lain:

- Pengembangan pasar untuk meraih market share lebih besar dengan penetrasi pasar dan penyerapan pasar dan atau pengembangan pasar baru bagi layanan yang ada saat ini.

- Pengembangan layanan baru untuk pasar yang ada dan atau pasar yang baru.

- Penetapan harga terhadap layanan yang dimiliki dan layanan baru dengan metode dinamik, penetrasi atau skimming. Metode penetrasi dan skimming terutama untuk layanan baru.

- Promosi layanan, antara lain mencakup metode, media dan materi promosi.

3. Strategi bidang keuangan

Strategi keuangan menguji implikasi keuangan dari pilihan strategis suatu unit bisnis dan mengidentifikasi langkah keuangan terbaik. Strategi ini juga dapat menciptakan keunggulan bersaing melalui biaya modal yang lebih rendah dan kemampuan untuk meningkatkan jumlah modal untuk mendukung strategi. 
4. Strategi bidang penelitian dan pengembangan

Strategi ini berkaitan dengan inovasi dan pengembangan layanan dan proses internal dengan tujuan untuk menjadikan perusahaan unggul dalam layanan dan proses internal dan tidak mudah ditiru oleh pesaing.

5. Strategi bidang teknologi informasi Strategi yang berkaitan dengan pemanfaatan teknologi informasi untuk menghasilkan keunggulan bersaing.

6. Strategi bidang operasional

Strategi operasional meliputi kualitas, proses dan fasilitas atau sumber daya fisik. Strategi ini berkaitan pula dengan pembelian dan logistik serta strategi bidang teknologi informasi.

\section{Metodologi Penelitian}

Penelitian ini merupakan penelitian kualitatif. Subyek penelitian adalah layanan kardiovaskular Eka Hospital Pekanbaru.

Populasi penelitian adalah direktur rumah sakit, direktur regional dan seluruh kepala yang terdiri dari divisi pelayanan medis, keperawatan, penunjang medis, pemasaran dan hubungan masyarakat, sumber daya manusia, umum, pengelolaan JKN dan layanan pelanggan. Populasi di atas merupakan individu individu yang memiliki kompetensi melakukan identifikasi dan analisis faktor strategis dari sudut pandang masing - masing divisi dan individu dengan kompetensi menilai dari keseluruhan operasional dan bisnis rumah sakit. Perumusan keputusan dalam manajemen rumah sakit umumnya bersifat kolektif dengan analisis dilakukan secara bersama via Forum Group Discussion. Seluruh populasi menjadi sampel dalam penelitian ini.

\section{Data Penelitian}

Data penelitian terdiri dari data kualitatif dan data kuantitatif. Sumber data adalah data primer yang merupakan data internal perusahaan dan data sekunder yang merupakan data eksternal.

Data primer bersumber dari:
- Laporan bulanan, tahunan rumah sakit

- Laporan bulanan dan tahunan divisi.

- Notulen pertemuan rutin manajemen setiap minggu, dihadiri direktur rumah, direktur regional, sakit dan seluruh kepala divisi.

- Notulen pertemuan manajemen dengan tim layanan kardiovaskular.

- Forum Group Discussion (FDG)

Data sekunder bersumber dari:

- Kementerian Kesehatan RI

- Dinas Kesehatan Propinsi Riau

- Dinas Kesehatan Kota Pekanbaru

- PERSI

- Kepustakaan

- Data marketing intelligence mengenai kompetitor.

\section{Teknik Pengumpulan dan Analisis Data}

Data primer dan sekunder di atas menjadi pedoman dalam penyusunan kuisioner yaitu dalam penentuan faktor faktor strategis internal dan eksternal yang akan menjadi komponen yang akan dinilai dalam kuisioner Internal Strategic Factors Analysis Summary (IFAS) dan kuisioner External Strategic Factors Analysis Summary (EFAS). Penentuan faktor - faktor strategis internal dan eksternal dilakukan melalui Forum Group Discussion oleh sampel penelitian.

\section{Kerangka Pemikiran}

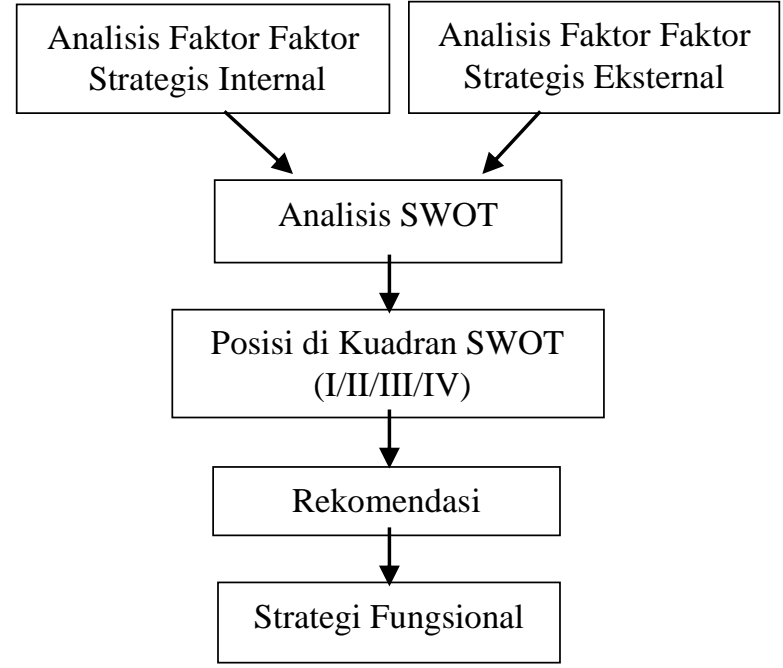

Faktor strategis internal dapat berupa kompetensi sumber daya manusia, kelengkapan layanan, mutu layanan, infrastruktur dan teknologi pendukung layanan, brand, harga, kekuatan promosi atau 
pemasaran, tingkat kepuasan pelanggan, performa keuangan, proses internal, kemampuan melakukan efisiensi dan faktor faktor lain. Faktor faktor di atas dapat menjadi kekuatan atau kelemahan perusahaan. Faktor strategis eksternal dapat berupa pasar dan pertumbuhannya, kompetitor baru, kemajuan kompetitor, regulasi dan perubahannya, pertumbuhan kelas menengah, kemajuan infrastruktur, pertumbuhan industri pendukung dan faktor faktor lain. Faktor faktor tersebut dapat menjadi peluang atau ancaman terhadap perusahaan.

Faktor strategis internal dimasukkan ke kuisioner IFAS sedangkan faktor strategis eksternal dimasukkan ke kuisioner EFAS. Langkah selanjutnya sebagai berikut:

- Pemberian nilai rating dan bobot untuk setiap faktor dalam kuisioner. Pemberian nilai dilakukan melalui FDG oleh sampel penelitian.

- Pemberian rating (a) dimulai dari 1.0 sampai 4.0 dan bersifat independen, yaitu faktor faktor di dalam faktor internal dan dalam faktor eksternal tidak saling mempengaruhi. Nilai rating berbanding lurus dengan pengaruh faktor tersebut terhadap layanan kardiovaskular.

- Pemberian bobot (b) dimulai dari terendah 0.01 sampai tertinggi 1.00 dan bersifat dependen, yaitu faktor faktor di dalam faktor internal saling mempengaruhi dan faktor faktor di dalam faktor eksternal juga saling mempengaruhi. Total nilai seluruh faktor di dalam faktor internal dan total nilai seluruh faktor di dalam faktor eksternal masing - masing maksimal 1.0. Semakin tinggi bobot semakin penting faktor tersebut di dalam faktor internal atau eksternal.

- Hitung perkalian rating dan bobot untuk setiap faktor.

- Hitung total hasil perkalian rating dan bobot setiap faktor dalam faktor kekuatan, kelemahan, peluang dan ancaman.

- Hitung selisih total perkalian rating dan bobot faktor kekuatan dengan faktor kelemahan dan menjadi nilai di titik $X$ serta selisih total perkalian rating dan bobot faktor peluang dengan faktor ancaman yang menjadi nilai di titik $\mathrm{Y}$.
- Nilai X dan Y diproyeksikan pada grafik kuadran SWOT dan diperoleh pertemuan titik di kuadran tertentu yang menunjukkan rekomendasi strategi berdasarkan analisis SWOT.

- Lakukan perumusan strategi di tingkat fungsional berdasarkan Forum Group Discussion (FGD) oleh sampel dalam penelitian ini.

\section{Hasil Penelitian}

\section{Profil Umum Perusahaan}

Eka Hospital merupakan jaringan rumah sakit swasta yang merupakan anak usaha dari Group Sinarmas. Eka Hospital Pekanbaru merupakan rumah sakit tipe B non pendidikan dan berlokasi di Jalan Soekarno Hatta Km 6.5. Eka Hospital Pekanbaru didukung 73 dokter spesialis, 36 dokter umum, 4 dokter gigi, 2 psikolog klinis, 263 perawat dan bidan serta didukung analis laboratorium, apoteker, asisten apoteker, radiografer, tenaga rekam medis, fisioterapis, terapis tumbuh kembang dan tenaga pendukung lain.

Eka Hospital Pekanbaru memiliki kapasitas 300 tempat tidur dengan 160 tempat tidur aktif. Eka Hospital mengunakan sistem informasi rumah sakit Vesalius sebagai rekam medis elektronik.

Eka Hospital Pekanbaru memulai layanan di November 2008. Di tahun 2019, Eka Hospital Pekanbaru telah memberikan layanan seperti yang terdapat di grafik di bawah ini.

Grafik 1.6. Performa Eka Hospital Pekanbaru Tahun 2019.

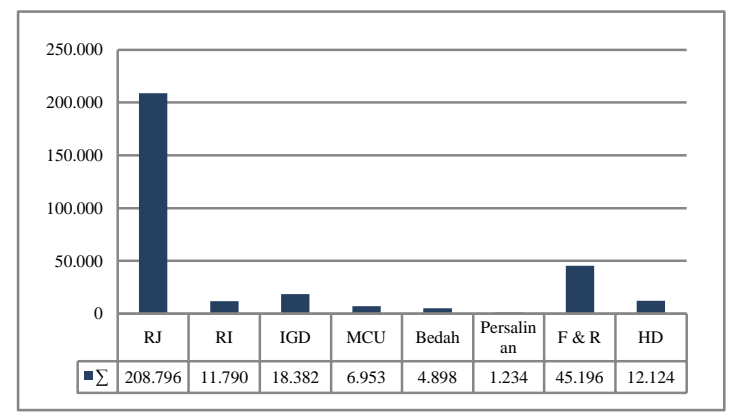

Keterangan: 


$$
\begin{aligned}
& \text { RJ : Jumlah pasien rawat jalan } \\
& \text { pertahun : Jumlah pasien rawat inap } \\
& \text { pertahun } \\
& \text { Bedah : Jumlah pembedahan pertahun } \\
& \text { Persalinan : Jumlah persalinan dalam satu } \\
& \text { tahun. } \\
& \text { HD : Jumlah kunjungan hemodialisa } \\
& \text { pertahun. }
\end{aligned}
$$

Sekitar 24.94\% dari kunjungan rawat jalan dan $33.75 \%$ dari pasien rawat inap di tahun 2019 merupakan pasien Jaminan Kesehatan Nasional (JKN).

\section{Profil Layanan Kardiovaskular Eka Hospital Pekanbaru}

Layanan kardiovaskular telah dimulai sejak awal operasional di November 2008 berupa layanan generik spesialis jantung dan pembuluh darah (kegawatdaruratan, rawat jalan, rawat inap, medical check up)

- Layanan subspesialis jantung anak dimulai setelah rekrutmen subspesialis jantung anak dan dimulai dengan layanan generik (rawat jalan, rawat inap dan kegawatdaruratan)

- Layanan kateterisasi intervensi mandiri dimulai setelah seorang spesialis jantung menyelesaikan pendidikan lanjutan lanjutan di bidang intervensi di RSUP Harapan Kita dan RS Anzhen Beijing.

- Layanan kateterisasi jantung pada kelainan jantung bawaan dimulai di semester kedua 2014 setelah persiapan layanan selesai.

- Layanan spesialis bedah jantung dan pembuluh darah dimulai setelah rekrutmen spesialis bedah thorak kardiovaskular di trimester pertama 2014 yaitu layanan generik (rawat jalan, rawat inap, kegawatdaruratan).

- Layanan bedah jantung dimulai di November 2014 setelah persiapan sumber daya manusia dan infrastruktur pendukung selesai.

- Layanan subspesialis elektofisiologi jantung untuk kelainan irama jantung dimulai setelah salah seorang spesialis jantung menyelesaikan pendidikan lanjutan bidang elektrofisiologi jantung di RSUP
Harapan Kita Jakarta di trimester kedua 2017.

- Layanan kateterisasi diagnostik dan ablasi pada kelainan irama jantung dimulai di trimester akhir 2017 setelah persiapan infrastruktur pendukung selesai dilakukan.

Penyakit jantung koroner merupakan penyakit terbanyak penyebab pasien dirawat inap di Eka Hospital di tahun 2018 dan 2019, mencapai $17.13 \%$ di 2019.

\section{Analisis Pasar}

Pasar utama layanan kardiovaskular rumah sakit di Propinsi Riau adalah penduduk di Riau. Populasi penduduk di Riau mengalami peningkatan rata-rata $3 \%$ setiap tahun yang menyebabkan peningkatan pasar untuk layanan kardiovaskular setiap tahun. Segmentasi Eka Hospital adalah kelompok middle middle class, upper middle class dan upper class. Populasi kelas menengah di Indonesia menunjukkan pertumbuhan termasuk di Propinsi Riau. Badan Pusat Statistik Propinsi Riau membuat pengelompokkan populasi berdasarkan pengeluaran perkapita perbulan sebagai berikut:

Grafik 1.6. Populasi Penduduk Menurut Pengeluaran Perkapita Perbulan

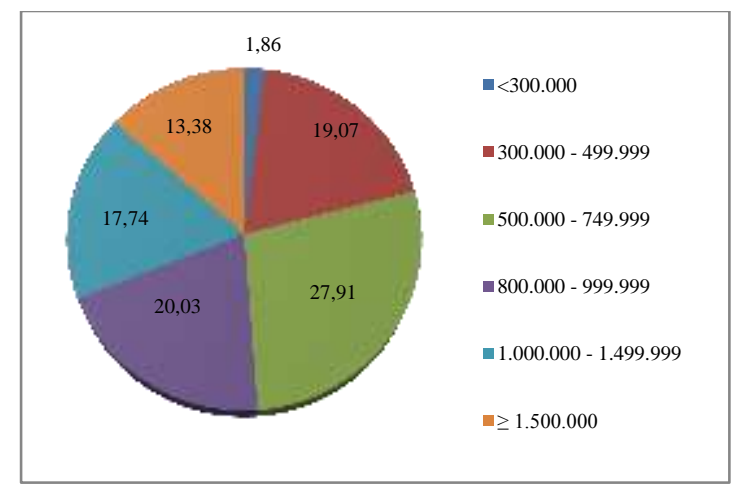

Bila menggunakan pengeluaran perkapita $\geq$ Rp 1.500.000 perbulan sebagai indikator batas untuk middle middle class maka populasi dari middle middle class, middle upper class dan upper class di Riau mencapai $13.38 \%$ atau 911,835 jiwa. Jumlah tersebut merupakan estimasi segmentasi pasar Eka Hospital. Hal 
ini mempertimbangkan indikator dari Asia Development Bank (ADB) untuk negara negara Asia, middle middle class adalah kelompok dengan pengeluaran perkapita 4 sampai 10 USD perhari atau 120 sampai 300 USD perbulan.

Berdasarkan data BPS tahun 2014, penduduk usia $\geq 35$ tahun mencapai $32.23 \%$ dari populasi. Bila diasumsikan persentase itu tidak berubah maka populasi penduduk Riau dengan usia $\geq 35$ tahun di 2018 dari kelompok middle middle, middle upperda $\mathrm{n}$ upper class mencapai 293,884 jiwa.

Berdasarkan RISKESDAS 2018, prevalensi penyakit jantung pada kelompok usia $\geq 35$ tahun mencapai $19.6 \%$ sehingga diperkirakan bahwa prevalensi penyakit jantung pada populasi penduduk middle middle, middle upper dan upper class usia $\geq$ 35 tahun di propinsi Riau mencapai 57,601 jiwa. Jumlah tersebut merupakan available market untuk layanan spesialis jantung dan pembuluh darah. Rata - rata kunjungan pasien rawat jalan ke klinik spesialis jantung dan pembuluh darah Eka Hospital Pekanbaru perbulan sekitar 850 pasien dengan $\pm 74 \%$ merupakan pasien dengan pembiayaan perusahaan, pribadi dan asuransi. Bila dibandingkan dengan available market di Riau terlihat bahwa masih terdapat potensi untuk memperbesar market share.

Rasio kelahiran bayi dengan penyakit jantung bawaan di Indonesia antara 4 - 50 per 1.000 kelahiran hidup dengan $25 \%$ di antaranya memerlukan prosedur bedah jantung dalam tahun pertama kehidupan. Berdasarkan Profil Kesehatan Indonesia Tahun 2016, jumlah kelahiran hidup di Propinsi Riau mencapai 153.055 kelahiran pertahun sehingga prevalensi penyakit jantung bawaan di Riau mencapai sekitar 612 sampai 7.650 anak pertahun dengan sekitar 153 sampai 1,912 anak membutuhkan prosedur bedah jantung. Bila menggunakan persentase kelompok middle middle, middle upper dan upper class yang sama maka populasi anak dengan penyakit jantung bawaan di Riau yang termasuk dalam kelompok tersebut sekitar 82 sampai 1,024 anak dengan 21 sampai 256 anak membutuhkan bedah jantung. Populasi di atas menggambarkan available market untuk Eka Hospital. Rata- rata kunjungan rawat jalan ke klinik subspesialis jantung anak Eka Hospital Pekanbaru perbulan mencapai 145 pasien di tahun 2019. Bila dibandingkan dengan available market maka terlihat potensi untuk meningkatkan volume pasar yang dilayani walaupun layanan subspesialisasi jantung anak hanya dimiliki Eka Hospital Pekanbaru di Riau sampai dengan saat ini.

Sistem Jaminan Kesehatan Nasional yang dikelola oleh Badan Penyelenggara Jaminan Sosial Kesehatan membentuk segmen pasar baru yang besar untuk industri rumah sakit. Jumlah peserta JKN terus mengalami peningkatan setiap tahun. Jumlah peserta JKN mengalami pertumbuhan mencapai $17.51 \%$ di tahun $2015,9.64 \%$ di tahun 2016 dan $9.35 \%$ di tahun 2017. Data per Juli 2019 mencatat bahwa jumlah peserta JKN telah mencapai 222.463.022 atau sekitar $82 \%$ dari jumlah populasi penduduk Indonesia. Jumlah peserta JKN diperkirakan akan terus meningkat karena didukung oleh peraturan pemerintah yang mewajibkan kepesertaan JKN baik untuk pekerja penerima upah maupun bukan penerima upah. Di Propinsi Riau, jumlah peserta JKN per - 4 Juli 2019 tercatat telah mencapai $74.69 \%$ jumlah penduduk Riau. Jumlah tersebut menunjukkan potensi pasar yang sangat besar termasuk untuk layanan kardiovaskular. Hal ini diikuti pula dengan peningkatan jumlah perusahaan yang menggunakan manfaat JKN untuk manfaat kesehatan untuk karyawan mereka sebagai bagian dari upaya efisiensi perusahaan.

Grafik 1.7. Pertumbuhan Jumlah Peserta JKN Tahun 2014 - 2017 


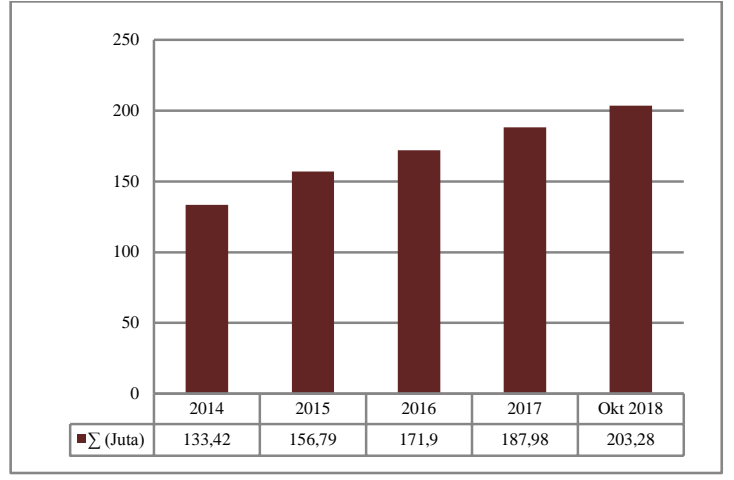

\section{Analisis Faktor Internal dan Eksternal}

Tabel 1.3. Tabel Internal Strategic Factors Analyis Sumamary (IFAS)

\begin{tabular}{|c|c|c|c|}
\hline Faktor & (a) & (b) & $\begin{array}{l}\mathrm{ax} \\
\mathrm{b}\end{array}$ \\
\hline \multicolumn{4}{|l|}{ Faktor Kekuatan } \\
\hline $\begin{array}{lr}\text { SDM pendukung layanan } \\
\text { di bidang kardiovaskular } \\
\text { relatif lebih lengkap } \\
\text { dibandingkan } \\
\text { kompetitor. }\end{array}$ & 4.0 & $\begin{array}{c}0.1 \\
0\end{array}$ & 0.40 \\
\hline $\begin{array}{l}\text { Jenis - jenis layanan di } \\
\text { bidang kardiovaskular } \\
\text { yang tersedia lebih } \\
\text { lengkap dibandingkan } \\
\text { dengan kompetitor. }\end{array}$ & 4.0 & $\begin{array}{c}0.1 \\
0\end{array}$ & 0.40 \\
\hline $\begin{array}{l}\text { Infrastruktur } \\
\text { infrastruktur layanan } \\
\text { kardiovaskular yang lebih } \\
\text { lengkap dibandingkan } \\
\text { dengan kompetitor }\end{array}$ & 4.0 & $\begin{array}{c}0.1 \\
0\end{array}$ & 0.40 \\
\hline $\begin{array}{l}\text { Sistem informasi rumah } \\
\text { sakit yang elektronik } \\
\text { yang canggih. }\end{array}$ & 4.0 & $\begin{array}{c}0.0 \\
2\end{array}$ & 0.08 \\
\hline $\begin{array}{l}\text { Sistem dokter penuh } \\
\text { waktu }\end{array}$ & 2.0 & $\begin{array}{c}0.0 \\
5\end{array}$ & 0.10 \\
\hline $\begin{array}{l}\text { Komitmen kuat terhadap } \\
\text { dari peningkatan } \\
\text { pengembangan } \\
\text { kompetensi tim yang } \\
\text { terlibat dalam layanan } \\
\text { kardiovaskular ran } \\
\text { pengembangan layanan }\end{array}$ & 2.0 & $\begin{array}{c}0.0 \\
5\end{array}$ & 0.10 \\
\hline
\end{tabular}

\begin{tabular}{|c|c|c|c|}
\hline $\begin{array}{l}\text { dari manajemen rumah } \\
\text { sakit. }\end{array}$ & & & \\
\hline \begin{tabular}{|lr} 
Komitmen dari & tim \\
layanan kardiovaskular \\
mendukung & upaya \\
pengembangan & dan \\
peningkatan & kualitas \\
layanan. & \\
\end{tabular} & 3.0 & $\begin{array}{c}0.0 \\
5\end{array}$ & 0.15 \\
\hline $\begin{array}{|lr|}\text { Keberhasilan } & \text { dalam } \\
\text { meraih } & \text { akreditasi } \\
\text { internasional } & \text { dan } \\
\text { akreditasi nasional. } & \\
\end{array}$ & 3.0 & $\begin{array}{c}0.0 \\
2\end{array}$ & 0.06 \\
\hline $\begin{array}{l}\text { Kekuatan brand Eka } \\
\text { Hospital }\end{array}$ & 2.0 & $\begin{array}{c}0.0 \\
2\end{array}$ & 0.04 \\
\hline Dukungan Pasar Internal & 3.0 & $\begin{array}{c}0.0 \\
2\end{array}$ & 0.06 \\
\hline $\begin{array}{l}\text { Performa keuangan yang } \\
\text { baik untuk layanan } \\
\text { kardiovaskular dan } \\
\text { kekuatan finansial yang } \\
\text { kuat dari organisasi. }\end{array}$ & 2.0 & $\begin{array}{c}0.0 \\
2\end{array}$ & 0.04 \\
\hline$\underline{\text { Total }}$ & & $\begin{array}{c}1.0 \\
0\end{array}$ & $\underline{1.83}$ \\
\hline \multicolumn{4}{|l|}{ Faktor Kelemahan } \\
\hline $\begin{array}{lr}\text { Jumlah dari } & \text { dokter } \\
\text { spesialis dan } & \text { subspesialis } \\
\text { pendukung } & \text { layanan } \\
\text { kardiovaskular } & \text { yang } \\
\text { terbatas. } & \\
\end{array}$ & 3.0 & $\begin{array}{l}0.1 \\
0\end{array}$ & 0.30 \\
\hline $\begin{array}{l}\text { Beberapa dari } \\
\text { infrastruktur pendukung } \\
\text { layanan telah out of date } \\
\text { dibandingkan dengan } \\
\text { teknologi terbaru di } \\
\text { dunia. }\end{array}$ & 2.0 & $\begin{array}{c}0.1 \\
0\end{array}$ & 0.20 \\
\hline $\begin{array}{l}\text { Layanan farmasi dan } \\
\text { layanan administrasi yang } \\
\text { belum memenuhi harapan } \\
\text { pelanggan dalam hal } \\
\text { kecepatan. }\end{array}$ & 3.0 & $\begin{array}{l}0.0 \\
5\end{array}$ & 0.15 \\
\hline $\begin{array}{l}\text { Tidak memiliki jaringan } \\
\text { RS dengan tipe bertingkat } \\
\text { di Riau untuk mendukung } \\
\text { rujukan pasien JKN dan } \\
\text { CoB. }\end{array}$ & 4.0 & $\begin{array}{l}0.0 \\
5\end{array}$ & 0.20 \\
\hline $\begin{array}{lr}\text { Saluran } & \text { distribusi } \\
\text { peralatan } & \text { kesehatan yang }\end{array}$ & 2.0 & $\begin{array}{l}0.0 \\
5\end{array}$ & 0.10 \\
\hline
\end{tabular}




\begin{tabular}{|c|c|c|c|}
\hline$b_{c}$ & & & \\
\hline $\begin{array}{l}\text { Tidak memiliki divisi } \\
\text { khusus penelitian dan } \\
\text { pengembangan layanan } \\
\text { kardiovaskular dan peran } \\
\text { dari penanggungjawab } \\
\text { layanan unggulan di } \\
\text { tingkat korporat yang } \\
\text { belum optimal. }\end{array}$ & 1.0 & $\begin{array}{c}0.0 \\
2\end{array}$ & 0.02 \\
\hline $\begin{array}{l}\begin{array}{l}\text { Dukungan yang lemah } \\
\text { dari } \\
\text { pemerintahan. }\end{array} \\
\text { birokrasi }\end{array}$ & 2.0 & $\begin{array}{c}0.0 \\
1\end{array}$ & 0.02 \\
\hline $\begin{array}{l}\text { Sentralisasi kewenangan } \\
\text { di tingkat korporat }\end{array}$ & 3.0 & $\begin{array}{c}0.0 \\
1\end{array}$ & 0.03 \\
\hline $\begin{array}{l}\text { Pemanfaatan sumber } \\
\text { daya yang kurang efisien } \\
\text { di dalam pengobatan dan } \\
\text { perawatan pasien. }\end{array}$ & 2.0 & $\begin{array}{c}0.0 \\
2\end{array}$ & 0.04 \\
\hline $\begin{array}{l}\text { Pengembangan dari } \\
\text { indikator indikator mutu } \\
\text { layanan relatif lambat dan } \\
\text { perbandingan indikator } \\
\text { mutu masih terbatas pada } \\
\text { jaringan Eka Hospital. }\end{array}$ & 1.0 & $\begin{array}{c}0.0 \\
2\end{array}$ & 0.02 \\
\hline $\begin{array}{lr}\text { Skema referral fee yang } \\
\text { kurang } & \text { menarik } \\
\text { dibandingkan } & \text { dengan } \\
\text { kompetitor. } & \\
\end{array}$ & 3.0 & $\begin{array}{c}0.0 \\
2\end{array}$ & 0.06 \\
\hline Total & & $\begin{array}{c}1.0 \\
0\end{array}$ & 1.14 \\
\hline $\begin{array}{l}X=(\mathrm{a} x \mathrm{~b}) \text { kekuatan - (a x } \\
\text { b) kelemahan }\end{array}$ & & & 0.69 \\
\hline
\end{tabular}

Tabel 1.4. Tabel External Strategic Factors Analyis Sumamary (EFAS)

\begin{tabular}{|c|c|c|c|}
\hline Faktor & (a) & (b) & $\begin{array}{c}\mathrm{ax} \\
\mathrm{b}\end{array}$ \\
\hline \multicolumn{4}{|l|}{ Faktor Peluang } \\
\hline $\begin{array}{l}\text { Available market yang } \\
\text { besar untuk layanan } \\
\text { kardiovaskular }\end{array}$ & 2.0 & 0.04 & 0.08 \\
\hline $\begin{array}{l}\text { Unserved market yang } \\
\text { besar untuk layanan } \\
\text { bedah jantung. }\end{array}$ & 4.0 & 0.10 & 0.4 \\
\hline \begin{tabular}{lr} 
Peraturan & \multicolumn{2}{r}{ Menteri } \\
Kesehatan & Nomor 30 \\
Tahun 2019. &
\end{tabular} & 3.0 & 0.05 & 0.15 \\
\hline
\end{tabular}

\begin{tabular}{|c|c|c|c|}
\hline $\begin{array}{l}\text { Pertumbuhan jumlah } \\
\text { peserta JKN setiap tahun }\end{array}$ & 2.0 & 0.05 & 0.1 \\
\hline \begin{tabular}{lr} 
Pertumbuhan & positif \\
\multicolumn{2}{l}{ asuransi kesehatan swasta } \\
disertai peningkatan \\
jumlah \\
kesehatan swasta yang \\
telah bekerjasama dengan \\
BPJS.
\end{tabular} & 2.0 & 0.02 & 0.04 \\
\hline $\begin{array}{l}\text { Layanan kateterisasi } \\
\text { jantung anak, kateterisasi } \\
\text { ablasi dan layanan bedah } \\
\text { jantung yang terbatas di } \\
\text { Propinsi Riau dan } \\
\text { Sumatera Bagian Tengah }\end{array}$ & 4.0 & 0.10 & 0.4 \\
\hline $\begin{array}{l}\text { Angka kunjungan pasien } \\
\text { ke Malaysia yang masih } \\
\text { tinggi didukung tarif } \\
\text { penerbangan yang relatif } \\
\text { murah dan akses yang } \\
\text { relatif mudah. }\end{array}$ & 2.0 & 0.02 & 0.04 \\
\hline $\begin{array}{l}\text { Kemajuan infrastruktur } \\
\text { akses antar propinsi, antar } \\
\text { kota/ kabupaten di } \\
\text { Propinsi Riau. }\end{array}$ & 2.0 & 0.02 & 0.04 \\
\hline $\begin{array}{l}\text { Kebijakan pemerintah } \\
\text { tentang rencana } \\
\text { penerapan bertahap B30 - } \\
\text { B100 dalam beberapa } \\
\text { tahun ke depan. }\end{array}$ & 1.0 & 0.01 & 0.01 \\
\hline $\begin{array}{l}\text { Sistem dan teknologi re- } \\
\text { use yang berkembang } \\
\text { pesat. }\end{array}$ & 3.0 & 0.05 & 0.15 \\
\hline $\begin{array}{lr}\text { Peningkatan } & \text { klaim } \\
\text { INACBGs } & \text { untuk } \\
\text { prosedur bedah CABG. }\end{array}$ & 4.0 & 0.08 & 0.32 \\
\hline $\begin{array}{l}\text { Kebijakan dana talangan } \\
\text { dari pihak perbankan. }\end{array}$ & 1.0 & 0.01 & 0.01 \\
\hline Total & & & 1.74 \\
\hline \multicolumn{4}{|l|}{ Faktor Ancaman } \\
\hline $\begin{array}{l}\text { Kompetitor baru } \\
\text { kemajuan } \\
\text { perkembangan } \\
\text { kompetitor }\end{array}$ & 4.0 & 0.10 & 0.40 \\
\hline $\begin{array}{lr}\text { Hambatan rekrutmen } \\
\text { SDM oleh regulasi } \\
\text { informal. }\end{array}$ & 2.0 & 0.04 & 0.08 \\
\hline
\end{tabular}




\begin{tabular}{|c|c|c|c|}
\hline $\begin{array}{l}\text { Kewajiban kepersertaan } \\
\text { JKN untuk perusahaan. }\end{array}$ & 1.0 & 0.01 & 0.01 \\
\hline $\begin{array}{l}\text { Upaya hijack dokter } \\
\text { spesialis, subspesialis dan } \\
\text { perawat ahli terkait } \\
\text { layanan kardiovaskular } \\
\text { oleh kompetitor. }\end{array}$ & 3.0 & 0.05 & 0.15 \\
\hline \begin{tabular}{lrr} 
Kegiatan & \multicolumn{2}{r}{ promosi } \\
kompetitor & dari & negara \\
tetangga & \multicolumn{2}{c}{ terutama } \\
Malaysia & yang & relatif \\
agresif. & &
\end{tabular} & 2.0 & 0.02 & 0.04 \\
\hline $\begin{array}{ll}\text { Upaya } & \text { efisiensi } \\
\text { perusahaan. } & \end{array}$ & 3.0 & 0.04 & 0.12 \\
\hline $\begin{array}{lr}\text { Regulasi pajak tentang } \\
\text { import alat kesehatan dan } \\
\text { nilai tukar rupiah } \\
\text { terhadap USD yang } \\
\text { rendah } & \text { serta } \\
\text { ketergantungan terhadap } \\
\text { industri alat }- \text { alat } \\
\text { kesehatan luar negeri. }\end{array}$ & 2.0 & 0.02 & 0.04 \\
\hline $\begin{array}{l}\text { Kenaikan premi untuk } \\
\text { peserta JKN - BPJS } \\
\text { mandiri }\end{array}$ & 3.0 & 0.02 & 0.06 \\
\hline $\begin{array}{l}\text { Peralihan pengelolaan } \\
\text { migas Blok Rokan dari } \\
\text { PT Chevron ke PT } \\
\text { Pertamina. }\end{array}$ & 4.0 & 0.05 & 0.20 \\
\hline $\begin{array}{l}\text { Kompetitor } \\
\text { membangun jerus } \\
\text { rumah sakit di Riau } \\
\text { dengan tipe bertingkat } \\
\text { untuk menguasai rujukan } \\
\text { berjenjang JKN dan JKN } \\
\text { CoB. }\end{array}$ & 3.0 & $\begin{array}{c}0.0 \\
4\end{array}$ & 0.12 \\
\hline $\begin{array}{l}\text { Penurunan klaim INA } \\
\text { CBGs bedah katub } \\
\text { jantung. }\end{array}$ & 4.0 & $\begin{array}{c}0.0 \\
4\end{array}$ & 0.16 \\
\hline $\begin{array}{l}\text { Persepsi tentan layanan } \\
\text { medis di Malaysia yang } \\
\text { lebih baik + promosi } \\
\text { negatif dari rumah sakit } \\
\text { kompetitor di Malaysia. }\end{array}$ & 3.0 & $\begin{array}{c}0.0 \\
2\end{array}$ & 0.06 \\
\hline Total & & $\begin{array}{c}1.0 \\
0\end{array}$ & 1.44 \\
\hline
\end{tabular}

\begin{tabular}{|l|l|l|l|}
\hline $\begin{array}{l}\mathrm{Y}=(\mathrm{a} \times \mathrm{b}) \text { peluang }-(\mathrm{a} x \\
\mathrm{b}) \text { ancamam }\end{array}$ & & & $\mathbf{0 . 3 0}$ \\
\hline
\end{tabular}

\section{Pemilihan Jenis Strategi Berdasarkan Kuadran SWOT}

Berdasarkan perhitungan di dalam tabel IFAS dan EFAS didapatkan:

\section{Nilai X}

$=$ kekuatan $(\mathrm{a} \times \mathrm{b})-$ kelemahan $(\mathrm{a} \times \mathrm{b})$

$=0.69$ (positif)

\section{Nilai Y}

$=$ Peluang $(\mathrm{a} \times \mathrm{b})-$ Ancaman $(\mathrm{a} \times \mathrm{b})$

$=0.30$ (positif)

Nilai $\mathrm{X}$ dan $\mathrm{Y}$ di atas diproyeksikan pada grafik kuadran SWOT dan didapatkan titik di Kuadran I. Hal ini menunjukkan strategi yang sesuai untuk layanan kardiovaskular Eka Hospital Pekanbaru adalah Strategi Progresif. Jenis strategi ini merupakan strategi yang telah dipilih sebelumnya sehingga dapat dikategorikan sebagai stability strategy yaitu tidak mengubah arah strategi yang telah ditetapkan dan dijalankan namun perlu dilakukan penyesuaian strategi tingkat fungsional sesuai dengan perubahan faktor faktor internal dan faktor - faktor eksternal.

Grafik 1.8. Proyeksi Nilai $\mathrm{X}$ dan $\mathrm{Y}$ Pada Kuadran SWOT

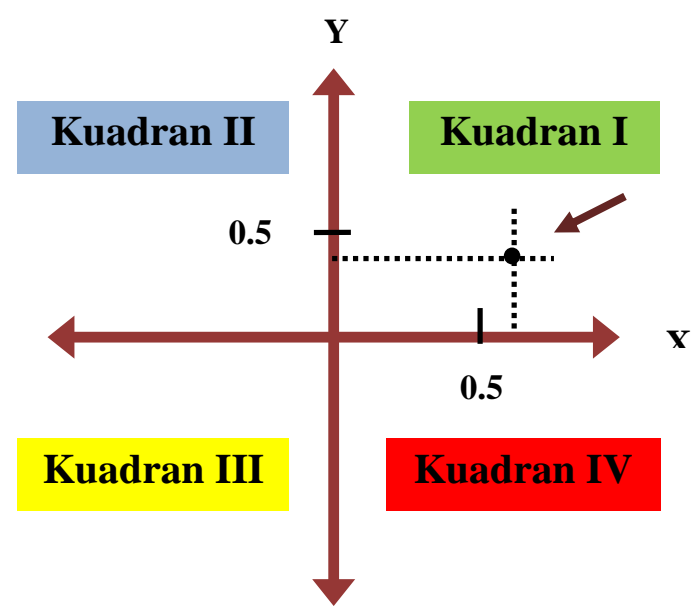

\section{Strategi Fungsional}

Perumusan strategi fungsional berdasarkan strategi progresif yang dipilih harus tetap mempertimbangkan faktor - faktor yang menjadi kekuatan, kelemahan, peluang 
dan ancaman. Perumusan dilakukan melalui FDG dengan melibatkan jajaran manajemen di tingkat rumah sakit mulai dari direktur rumah sakit, seluruh kepala divisi serta tim layanan kardiovaskular. dilakukan:

Berikut strategi fungsional yang perlu

\section{Strategi Pengembangan Sumber Daya Manusia}

Tujuan strategi di bidang sumber daya manusia adalah untuk:

- Menjamin kontinuitas layanan.

- Meningkatkan kapasitas layanan yang akan memberikan dampak pada potensi peningkatan revenue rumah sakit.

- Menambah jenis layanan yang belum dimiliki untuk mencapai layanan yang komprehensif.

- Melakukan retensi sumber daya manusia yang dimiliki terutama sumber daya manusia ahli dari potensi hijack.

Untuk mencapai tujuan di atas diperlukan strategi fungsional yang mencakup:

\section{Program Rekrutmen}

- Menyusun skala prioritas 1, 2 dan 3 dalam rekrutmen dan target waktu pemenuhan.

Prioritas satu harus dapat dipenuhi dalam waktu setidaknya lima tahun sejak strategi fungsional disusun.

- Membangun kerjasama dengan pusatpusat pendidikan spesialis dan subspesialis di Indonesia sebagai sumber untuk mendapatkan sumber daya spesialis maupun subspesialis, antara lain Universitas Indonesia, Universitas Airlangga, Universitas Padjajaran dan membangun peluang untuk menjadikan Eka Hospital sebagai bagian dari jaringan rumah sakit pendidikan dari pusat - pusat pendidikan di atas.

- Melakukan pendekatan dengan perhimpunan profesi di bidang kardiovaskular berkaitan dengan izin penambahan spesialis dan subspesialis didukung pendekatan informal via subspesialis yang bekerja di jaringan rumah sakit Eka Hospital dan memiliki jabatan struktural dan atau pengaruh di dalam perhimpunan profesi di bidang kardiovaskular di tingkat nasional.

2. Program pembiayaan pendidikan spesialis dan subspesialis untuk staf medis dan keperawatan.

- Program pembiayaan rumah sakit fokus untuk pendidikan subspesialis untuk dokter spesialis dan untuk pendidikan spesialis untuk perawat.

- Pembatasan pembiayan untuk seminar dan workshop yang tidak menambah jenis kompetensi terutama seminar dan workshop yang dilakukan di luar negeri sehingga biaya pendidikan dan pelatihan rumah sakit dapat dioptimalkan untuk program pendidikan subspesialis dan atau untuk pelatihan yang menambah jenis kompetensi dari tim layanan kardiovaskular.

3. Program pengembangan unit pelatihan internal.

Eka Hospital perlu mengembangkan pelatihan internal yang dimiliki saat ini menjadi pusat pelatihan internal dan eksternal di Propinsi Riau untuk bidang keperawatan kardiovaskular. Langkah ini sekaligus akan memudahkan upaya untuk memperoleh SDM keperawatan bidang kardiovaskular bila dibutuhkan. Strategi ini perlu dicapai dalam rentang waktu lima tahun ke depan.

4. Program retensi

Program retensi yang telah dimiliki Eka Hospital perlu dievaluasi dan disesuaikan berkala terutama berkaitan dengan sistem insentif yang berlaku untuk tim layanan kardiovaskular.

\section{Strategi Pengembangan Infrastruktur Pendukung Layanan}

Keunggulan pada infrastruktur dan teknologi pendukung layanan di bidang kardiovaskular perlu dipertahankan dan ditingkatkan untuk berkompetisi di tingkat regional. Tantangan utama yang dihadapi adalah dalam membentuk harga layanan yang 
kompetitif dengan tetap melakukan investasi untuk meregenerasi peralatan dalam rangka meningkatkan kualitas layanan kardiovaskular di tengah faktor efisiensi menjadi faktor dominan dalam pasar yang semakin didominasi JKN.

1. Melakukan analisis yang lebih mendalam dalam penyusunan skala prioritas investasi dengan melibatkan tim layanan kardiovaskular.

2. Memaksimalkan mekanisme trade-in dalam regenerasi peralatan penunjang layanan kardiovaskular dengan nilai investasi yang tinggi atau merelokasi peralatan lama ke jaringan rumah sakit yang baru. Mekanisme trade-in akan mengurangi nilai investasi sehingga mengurangi dampak biaya layanan yang tinggi akibat nilai depresiasi peralatan baru. Relokasi peralatan lama ke jaringan rumah sakit baru akan membantu rumah sakit baru untuk membentuk harga layanan yang lebih kompetitif di awal operasional rumah sakit karena tidak menghitung nilai depresiasi

3. Melakukan analisis terhadap peralatan yang diproduksi oleh negara - negara selain Amerika, Eropa dan Jepang yang menjadi preferensi untuk investasi peralatan sebelumnya terutama untuk peralatan penunjang layanan dengan teknologi canggih, misal: Cina dan India. Hal di atas untuk mendapatkan peralatan dengan nilai investasi yang lebih rendah namun tetap memiliki kualitas yang baik.

4. Melakukan evaluasi teknologi dan infrastruktur pendukung sistem re-use.

Sistem re-use dapat menurunkan biaya dasar layanan terutama pada komponen alat kesehatan yang berbiaya tinggi. Sistem re-use perlu dipertimbangkan untuk memperluas layanan terhadap pasar JKN. Sistem re-use harus tetap memperhatikan aspek keamanan dan keselamatan pasien serta mutu layanan.

\section{Strategi Pengembangan Layanan}

Tujuan strategi ini untuk mencapai layanan komprehensif, memiliki kualitas yang baik dan mampu berkompetisi dengan pusat layanan kardiovaskular di nasional dan regional. Pencapaian di atas akan meningkatkan tingkat kepercayaan pelanggan masyarakat terhadap layanan kardiovaskular Eka Hospital dan akan memberikan dampak pada pencapaian market share yang optimal.

1. Membentuk divisi khusus penelitian dan pengembangan layanan untuk menyusun perencanaan strategis jangka menengah dan jangka panjang layanan kardiovaskular Eka Hospital.

2. Mengembangkan layanan-layanan baru di bidang kardiovaskular yang belum dimiliki Eka Hospital Pekanbaru.

3. Meningkatkan kerjasama dengan pusat - pusat layanan kardiovaskular untuk transfer skill and knowledge terutama dengan pusat- pusat layanan yang telah memiliki hubungan kerjasama, antara lain RSUPN Jantung Harapan Kita, RSUP Cipto Mangunkusuko, IJN dan RS Universitas Beijing. Kerjasama ini bertujuan untuk kemudahan akses untuk pendidikan dan pelatihan dalam peningkatan kompetensi staf medis dan keperawatan Eka Hospital dan untuk pengembangan layanan kardiovaskular yang dimiliki Eka Hospital.

4. Membangun kluster rawat inap khusus untuk pasien - pasien dengan penyakit kardiovaskular dengan kualifikasi SDM dan infrastruktur sesuai dengan kebutuhan dalam pemantauan dan perawatan pasien dengan penyakit kardiovaskular. Estimasi jumlah tempat tidur adalah dengan target okupansi (BOR) mencapai $\geq 80 \%$.

5. Mengembangkan unit perawatan intensif khusus penyakit kardiovaskular (CVCU) yang terpisah dari ICU yang dimiliki saat ini. Hal ini bertujuan untuk meningkatkan kualitas perawatan dengan dukungan kualifikasi SDM dan infrastruktur yang sesuai dengan kebutuhan dalam pemantauan dan perawatan pasien dengan penyakit kardiovaskular. 
6. Mengembangkan indikator mutu layanan kardiovaskular sesuai dengan indikator mutu yang dipantau di pusat - pusat layanan kardiovaskular di tingkat regional Asia dan di tingkat dunia untuk memudahkan benchmark dan dalam rangka meningkatkan mutu layanan kardiovaskular.

7. Melakukan evaluasi dan perubahan standar layanan kardiovaskular secara berkala sesuai dengan perkembangan ilmu kedokteran di bidang kardiovaskular untuk mencapai standar layanan yang optimal.

\section{Strategi Pemasaran}

Strategi ini bertujuan untuk memperluas pasar dan memaksimalkan market share.

1. Perluasan pasar dari segmen JKN BPJS dengan memaksimalkan pengendalian biaya dan mutu.

- Memperluas kapasitas layanan untuk pasien JKN BPJS untuk jenis layanan kardiovaskular dengan ratio klaim INA CBGs terhadap biaya rumah sakit $\geq$ $70 \%$.

- Menyusun paket paket layanan kardiovaskular dengan volume tinggi, antara lain layanan kateterisasi pembuluh darah jantung, kateterisasi elektrofisiologi diagnostik dan ablasi serta bedah jantung. Paket - paket itu ditujukan untuk segmen pasar JKN $\mathrm{CoB}$ dengan target $\mathrm{CoB}$ maksimal $30 \%$ dari biaya rumah sakit pada pasien non JKN.

- Mengevaluasi terhadap potensi efisensi komponen - komponen di dalam layanan kardiovaskular terutama komponen obat dan alat kesehatan dan melakukan subsitusi ke obat dan alat kesehatan sesuai dengan formularium untuk layanan JKN.

- Menyusun formularium obat dan alat kesehatan yang terpisah untuk layanan JKN. Langkah ini linier dengan pemilihan saluran distribusi obat dan alat kesehatan non premium untuk menurunkan biaya dasar layanan.

- Mengoptimalkan pemanfaatan dari teknologi re-use yang tersedia untuk layanan pasien pasien JKN. Pemanfaatan teknologi re-use harus tetap memperhatikan mutu layanan dan prinsip - prinsip keamanan dan keselamatan pasien.

2. Melakukan penetrasi pasar lebih agresif ke kabupaten / kota di luar Pekanbaru terutama Kabupaten Pelalawan dan Kota Dumai serta Propinsi Jambi

- Memperluas jaringan rumah sakit di kabupaten / kota di Riau, Jambi dan Sumatera Barat terutama rumah sakit pemerintah sebagai sumber rujukan pasien (feeder) dengan penawaran manfaat berupa:

a. Kuota peserta untuk seminar dan workshop medis dan keperawatan yang dilakukan Eka Hospital Pekanbaru.

b. Kuota peserta untuk pelatihan internal keperawatan dan medis yang dilakukan di Eka Hospital /pelatihan lain sesuai dengan kebutuhan rumah sakit rujukan baik dilakukan di Eka Hospital maupun di rumah sakit terkait.

c. Program reward untuk dokter yang menjadi feeder untuk Eka Hospital berupa dukungan pembiayaan untuk kegiatan ilmiah dengan pengaturan nilai pembiayaan berdasarkan nilai rujukan.

3. Mengidentifikasi pasar baru; asuransi maupun perusahaan dan pasar dengan market share di bawah $60 \%$ terutama pasar dengan potensi menjadi substitusi pasar Chevron setelah peralihan ke PT Pertamina Persero.

4. Media dan Materi Promosi

- Mengoptimalkan peran dari media sosial sebagai media promosi dan mengurangi media promosi luar ruang dan media cetak.

- Mengubah materi promosi dari jenis layanan ke kombinasi antara jenis layanan dan pencapaian indikator mutu layanan serta perbandingan dengan pencapaian mutu layanan di pusat pusat layanan kardiovaskular di tingkat nasional dan regional. 
- Seminar medis, seminar awam, seminar web bekerjasama dengan pemerintah kabupaten/kota.

- Melakukan kerjasama dengan platform digital SehatQ untuk layanan kardiovaskular digital, antara lain telemedicine.

\section{Strategi Perbaikan Proses Internal}

1. Mempertahankan Akreditasi Nasional Paripurna KARS dan Akreditasi International JCI.

2. Melakukan sentraliasi call center untuk jaringan rumah sakit Eka Hospital.

3. Memanfaatkan investasi advanced hospital information system yang baru untuk mendukung perbaikan proses internal yang berfokus pada efisien waktu tanpa menghilangkan aspek - aspek keamanan dan keselamatan pasien. Prioritas perbaikan proses internal yaitu sistem dokumentasi medis dan keperawatan, sistem administrasi rawat inap dan sistem farmasi dengan target tingkat kepuasan pelanggan terhadap ketiga layanan di atas mencapai di atas $96 \%$ dengan konektivitas sistem informasi rumah sakit dengan seluruh infrastruktur penunjang layanan kardiovaskular.

4. Melanjutkan program pelatihan internal mengenai nilai dan budaya kerja secara konsisten.

\section{Kesimpulan}

Rekomendasi strategi untuk layanan kardiovaskular Eka Hospital Pekanbaru adalah strategi progresif atau growth oriented strategy. Rekomendasi ini menunjukkan bahwa Eka Hospital memiliki layanan kardiovaskular yang kuat dan peluang yang baik. Upaya upaya yang dilakukan Eka Hospital harus diarahkan untuk mencapai pertumbuhan yang agresif. Strategi di tingkat fungsional harus mendukung upaya pertumbuhan yang agresif. Selisih nilai faktor kekuatan dan faktor kelemahan juga selisih nilai faktor peluang dan faktor ancaman adalah positif namun selisih antara faktor peluang dan faktor ancaman lebih kecil. Hal ini menunjukan bahwa faktor faktor eksternal yang menjadi ancaman perlu menjadi fokus perhatian dalam perumusan strategi di tingkat fungsional.

\section{Saran}

Penelitian lanjutan dengan data lebih besar dan lebih lengkap terutama data benchmark dapat dilakukan untuk menghasilkan analisis yang lebih akurat dalam menentukan rekomendasi strategi. Penggunaan metode analisis yang berbeda dapat dilakukan untuk menilai ada tidak perbedaan rekomendasi strategi dibanding dengan penggunaan analisis SWOT dan menilai apakah analisis SWOT masih efektif. Penilaian ulang terhadap layanan atau bisnis setelah penerapan rekomendasi strategi dari analisis SWOT dan strategi fungsional yang diturunkan perlu dilakukan untuk menilai efektifitas dari analisis SWOT dalam menentukan rekomendasi jenis strategi.

\section{Daftar Pustaka}

Aaker,David. 2013. Manajemen Pemasaran Strategis Edisi VIII. Jakarta: Penerbit Salemba Empat.

Amir, Taufik. 2012. Manajemen Strategik, Konsep dan Aplikasi Edisi II. Jakarta: PT Rajawali Pers.

Assauri, Sofjan. 2013. Strategic Management: Sustainable Competitive Advantages. Jakarta: PT Rajawali Pers.

Badan Penelitian dan Pengembangan Kesehatan Kemenkes RI . 2019. Laporan Nasional Riset Kesehatan Dasar 2018 Hal 127, 129, 146, 154, 156. Jakarta: Lembaga Penerbit Badan Penelitian dan Pengembangan Kesehatan Kementerian Kesehatan Republik Indonesia.

Badan Pusat Statistik Propinsi Riau. 2017. Propinsi Riau Dalam Angka 2016 Hal 155. Riau: Badan Pusat Statistik Propinsi Riau. www.riau.bps.go.id 
Emelia B, Michael J, Stephanie E, Mary C, Rajat D, et.al. Januari 2017. Heart Disease and Stroke Statistics 2017 Update. American Heart Association Journal. www.circ.ahajournals.org

Chaffee, Ellen. 2010. Three Models of Strategy. Academy of Management Review, 1885, Vol 10, No.1, Hal 89-98.

Fine, Lawrence. 2009. SWOT Analysis: Using Strength to Overcome Weaknesses ,Using Opportunities to Overcome Threats. http://www.lawrencefine.com

Garbelli, Maria. Maret 2014. From Strategic Business Unit to Interfirm Srategic Business Unit : Theorethical Framework to Internal Business Process Performance and Placement. European Scientific Journal Vol.10,No.7. www.eujournal.org

Gibis B, Artiles J, Corabian P, Meiesaar K, Coppel A, Jacobs P, Serrano P, Menon D. 2001. Application of Strengths, Weaknesses, Opportunities and Threats Analysis in the Development of a Health Technology Assessment Program. Health Policy Vol 58: 27 - 35.

Harrison, Jeffrey. 2010. Essentials of Strategic Planning in Healthcare Ed II. Chicago: Health Administration Press.

Hartono, Bambang. 2010. Manajemen Pemasaran Untuk Rumah Sakit. Jakarta: Penerbit Rineka Cipta.

Johnson G, Kevan S dan Richard W. 2008. Exploring Corporate Strategy Ed VIII. New Jersey, US: Prentice Hall.

Kahveci dan Meads C. 2008. Analysis of Strengths, Weaknesses, Opportunities and Threats in Development of Health Technology Assessment Program. International Journal of Technology Assessment in Health Care Vol 24: 235-40. www.ncbi.nlm.nih.gov/pubmed

Kementerian Kesehatan RI. Desember 2013. Riset Kesehatan Dasar 2013 Hal 91 - 93. Jakarta: Badan Penelitian dan
Pengembangan Kesehatan Kementerian Kesehatan RI. www.depkes.go.id

Kementerian Kesehatan RI. 2014. Permenkes Nomor 56/Menkes/Per/IX/ 2014 pasal 26, pasal 37 dan lampiran.

Kementerian Kesehatan RI. Profil Kesehatan Indonesia Tahun 2015 Bab II Hal 34 - 36. Jakarta: Kementerian Kesehatan RI. www.depkes.go.id

Krause, Josef. 2012. Basic Characteristics of Corporate Strategy and Firm Value. Business Systems and Economis Journal. www.mruni.eu

Laksono T, Elisabeth L. 2018. Pertumbuhan Rumah Sakit Publik di Indonesia. www.persi.or.id

Mozaffarian D, Emelia J, Allan S, Donna K, et.al. Januari 2016. Executive Summary: Heart Disease and Stroke Statistics 2016. American Heart Association Journal. www.circ.ahajournals.org

Mulia, Elvie. 2014. Cost Reduction Strategies: Mengoptimalkan Efisiensi dan Efektivitas Jangka Panjang Perusahaan. Jakarta: PT Elex Media Komputindo.

Nickols, Fred.2016. Strategy, Strategic Management, Planning and Thinking. www.nickols.us/strategy

Nickols, Fred. 2016. Definitions and Meanings. www.nickols.us/strategy

Pusat Data dan Informasi Kementerian Kesehatan RI. 2017. Profil Kesehatan Indonesia 2016 Hal 32, 35, 79. Jakarta: Kementerian Kesehatan Republik Indonesia. www.depkes.go.id

Rangkuti, Freddy. 2015. Analisis SWOT: Teknik Membedah Kasus Bisnis, Cara Perhitungan Bobot, Rating dan OCAI. Jakarta : PT Gramedia Pustaka Utama.

Rangkuti, Freddy. 2014. SWOT Balanced Scorecard, Teknik Menyusun Strategi 
Korporat Efektif Plus Mengelola Kinerja dan Risiko. Jakarta: PT Gramedia Pustaka Utama.

Roth G, Huffman M, Roth A, Moran A, Feigin V, Mensah G, Naghavi M, Murray C. Oktober 2015. Global Burden of Cardiovascular Disease: Global and Regional Patterns in Mortality from 1990 to 2013. www.circ.ahajournals.org

Tim FME. 2013. SWOT Analysis, Strategy Skills.www.free-management-ebooks.com

Valentin, Erhard K. 18 Januari 2011. Away With SWOT Analysis: Use Defensive or Offensive Evaluation Instead. The Journal of Applied Business Research Vol 21 No 2. www.cluteinstitute.com

Wheelen, Thomas L dan David H. 2012. Strategic Planning and Business Policy toward Global Sustainability Ed XIII. New Jersey, US : Prentice Hall.

Wheelen, Thomas L dan David H. 2003. Manajemen Strategis Edisi Bahasa Indonesia. Yogyakarta: Penerbit Andi.

WHO Media Centre. Mei 2017. Cardiovascular Disease. $w$ ww. who.int

Yelder, Paul. 1999. Effective Strategic Planning. US : Enterprise Foundation. www.pcnrc.files.wordpress.com 